\title{
Development new rice varieties in the coastlines of Mekong Delta, Vietnam
}

\author{
Nguyen Thi Lang ${ }^{1}$, Nguyen Thi Hong Loan, Nguyen Trong Phuoc ${ }^{1}$, Le Hoang \\ Phuong ${ }^{1}$, Vo Hoai Chan ${ }^{2}$, Bui Chi Buu ${ }^{1}$
}

${ }^{1}$ High Agricultural Technology Research Institute for Mekong delta, Vietnam (HATRI)
${ }^{2}$ High Agricultural Technology Center Ben Tre Province, Vietnam

\begin{abstract}
To increase productivity and improve quality, new rice varieties need to be salinity tolerance and resistant to many kinds of insects, diseases, and high levels of nutrients, resistant to disadvantageous conditions, and promises to reduce using pesticides, chemical fertilizers. Great efforts have been focused on germplasm research to discover genes resistant to disease and insect, efficient in using salinity level with good grain quality and productivity. With the development of climate-resilient varieties, scaling up or dissemination of seeds is done by province, following the locality's is Winter-Spring (DongXuan Season) and Summer-( Wet season ). For instance, in the case of Winter-Spring crop, the plan of Mekong delta is to expand some lines such as HATRI 190, HATRI 192, HATRI 170were developed that can yield4-5 tons ha ${ }^{-1}$ under salt stress of 10.0 to $12.0 \mathrm{dS} \mathrm{m}^{-1}$, and are being out-scaled. Normally, this expansion initiative requires inclusion of key rice varieties, that is, local or extra varieties and promising varieties, all of which will be included in the plan for developing the rice sector for each province.
\end{abstract}

Keywords-rice varieties, improve quality, salinity tolerance.

\section{INTRODUCTION}

Rice is a major export commodity of Vietnam and a source of livelihood of smallholder farmers, particularly in the Mekong Delta, which contributes more than fifty percent of the country's total rice production. Millions of farmers in the Delta are living below poverty level as their farming is affected by occurrences of drought, flooding, and salinity from saltwater intrusion. An estimated 1,867,910 hectares of the total rice crop area is affected by salinity( Buu et al 2004).High Agricultural Technology Research Institute for Mekong delta(HATRI) recognizes the importance of developing modern climate-resilient rice varieties as well as associated management practices that respond to the challenges of climatic variability in such stress-prone areas. In the case of Vietnam, a rice variety that will be seedmultiplied, first needs to undergo evaluation trials at the HATRI. Moreover, an equally daunting task is bringing the new varieties to the farmers' fields where productivity is still not at optimal level due and where there are institutional constraints related to extension activities. Country protocol for varietal release and dissemination requires that provincial officers and farmers will have to be invited to assess the performance of the varieties in the field. Upon initial assessment and acceptance, farmers and local staff in the districts and provinces will evaluate the variety this time for deployment and multiplication (Lang et al 2016a). This is an ideal strategy to bring rice varieties to the local farmers. The MARD, IFAD-CURE, and other funding institutions, which share the same goal of raising productivity in the salinityprone rice areas in the Mekong Delta, supported the development, validation (Lang et al 2015), and eventual dissemination of climate-smart varieties. The key in achieving such goal involves partnerships and participatory approaches for a need-based strategy of developing varieties and eventual delivery to farmers from 2017-2018.The estimated rice production for the three rice growing seasons 2015 correlates well with data at the district level collected from the province statistics offices with R2s of 0.93 for the Winter-Spring, 0.86 for the Summer-Autumn and 0.87 for the Autumn-Winter season(Kersten Clauss et al 2018) Our research activities in the Mekong Delta focus on the 
development of proper technologies for Cultivating climateresilient rice varieties in the coastlines of Mekong Deltat enhancing and stabilizing farm level productivity and for improving farmers livelihoods. This is being achieved through the development of rice varieties with tolerance to prevailing abiotic stresses, adoption of proper soil, water for higher and stable productivity of these varieties .These efforts are being supported in part, by funds provided by the Program on salinity for climated change through Tay Nam Bo project.

\section{MATERIAL AND METHODS}

Some lines 24 lines obtained from the High Agricultural Technology Research Institute for Mekong delta, Vietnam (HATRI).

\section{Phenotype analysis}

A field experiment was transplanted to an irrigated lowland field in a randomized complete block design in three replications in the field of HATRI at BinhThuy, Can Tho. 24 lines with their parents were used to evaluate agronomic characteristics and salinity detection through sensory test and genotypic analysis using SSR markers in lab of HATRI. Data on important agronomic traits like plant height, panicle length, filled grains/panicle, unfiled grain/panicle, 1000grain weight, harvest index and yield were recorded.

Ten randomly selected plants of each genotype were used for agronomic data analysis. Data on plant height $(\mathrm{cm})$, number of effective tillers/plants, panicle length $(\mathrm{cm})$, number of filled grains/panicle, 1000-grain weight (g), days to maturity and grain yield/plant $(\mathrm{g})$ were recorded and subjected to statistical analyses using SAS software. After harvesting, the seeds of each genotype were dehulled for evaluation of the grain quality and aroma. The grains were classified into different types based on their dimension according to Dela Cruz and Khush.1989 . Ten seeds of each cultivar removed rice hull and mashed by hand. Take rice powder of each cultivar and put on each experimental tube or petri dish. Add $5 \mathrm{ml} \mathrm{KOH} 1.7 \%$ into each petri dish and cover. Store the samples in room temperature for 30 minutes. The samples were scored, corresponding to absence of aroma, slight aroma, moderate aroma and strong aroma, respectively.
Technology evaluation and adaptation. While varieties have already been developed that should be adapted to the local conditions, it is still necessary to evaluate their performance to meet national varietal release requirements. As these varieties perform completely differently undersality conditions than current varieties, comprehensive management practices must be developed so that farmers can fully benefit from them. This will involve (a) initiating testing programs of new varieties in various locations in all province deemed to be susceptible to salinity; (b) conducting comparisons of differing sources of salinitytolerance and combinations of sources to determine which are best suited for different salinity affected areas (different levelstress); (c) conducting of field trials (on-farm and on-station) to refine best management practices for each location; and (d) obtaining feedback results from field and agronomic experiments into varietal development and gene identification programs.

\section{Data Analysis}

The agro-morphological data were initially analyzed through examining variance to verify genetic variation in the traits measured. The few traits with insignificant genetic variation, based on the F-test, were not considered for further analyses

\section{RESULTS AND DISCUSSION}

\section{Breeding for salinity tolerance in rice}

The results show that some lines such as at 20 days after transplanting. At 35 days after transplanting, the highest variety was Evaluation of breeding lines from with local check varieties namely Pokkali and OXY 10 is conducted regularly in both wet season 2018. These lines are evaluated in farmers' fields as well as on station at HATRI. Different traits were assessed, including crop duration, plant height, panicle/ filling and sterility/ plants, quality traits as well as salinity tolerance. Lines that are early maturing (90-110 days) semi dwarf $(90-110 \mathrm{~cm})$ with medium number of panicles/hill (7-15 panicles) and high number of grains/panicle (77-199 grains) were selected for further testing in rice-rice cropping pattern when their salinity tolerance is high (survival after 20-25 day salinity at EC $=8$ DS/m) and duration of about $98 \mathrm{~d}$, similar to OXy 10. They were these lines will be suitable for salitniy affected(Table 1) 
Table 1. Yield and yield components of rice varieties tested at HATRI

\begin{tabular}{|c|c|c|c|c|c|c|c|}
\hline No. & Lines & $\begin{array}{c}\text { Panicles/ } \\
\text { plants (no.) }\end{array}$ & $\begin{array}{c}\text { Filled } \\
\text { grains/ } \\
\text { Panicle } \\
\text { (no.) }\end{array}$ & $\begin{array}{c}\text { unFilled } \\
\text { grains/ } \\
\text { Panicle } \\
\text { (no.) }\end{array}$ & $\begin{array}{c}\text { P } 1000 \text { grains } \\
(\mathrm{g})\end{array}$ & $\begin{array}{c}\text { yield (g/10 } \\
\text { plants) }\end{array}$ & $\begin{array}{c}\text { \% Survival } \\
\text { in sality EC- } \\
8 D S / m\end{array}$ \\
\hline 1 & IR28 (Checked) & $18 \mathrm{c}$ & $198 \mathrm{~d}$ & 121 & $26.7 \mathrm{cde}$ & $75 \mathrm{~m}$ & $5.2 \mathrm{v}$ \\
\hline 2 & Pokkali (checked) & $16 \mathrm{de}$ & $148 n$ & $14.2 \mathrm{j}$ & $26.8 \mathrm{~cd}$ & $56.5 \mathrm{t}$ & $78.8 \mathrm{i}$ \\
\hline 3 & HATRI 402 & $17 \mathrm{~cd}$ & $77 x$ & $14.2 \mathrm{j}$ & $27.6 \mathrm{~b}$ & $99 \mathrm{~g}$ & $45.8 \mathrm{mn}$ \\
\hline 4 & HATRI503 & 16 de & $169 \mathrm{i}$ & $14.5 \mathrm{ij}$ & $26 \mathrm{~g}$ & $95 \mathrm{i}$ & $45.6 \mathrm{n}$ \\
\hline 5 & HATRI506 & 15 ef & $210 \mathrm{c}$ & $16.8 \mathrm{f}$ & $26.8 \mathrm{~cd}$ & $93 \mathrm{j}$ & $47.8 \mathrm{k}$ \\
\hline 6 & HATRI 507 & $18 \mathrm{c}$ & $230 \mathrm{a}$ & $16.9 \mathrm{f}$ & $27 \mathrm{c}$ & $94 i$ & $42.3 \mathrm{~s}$ \\
\hline 7 & HATRI 506 & $12 \mathrm{~g}$ & $120 \mathrm{t}$ & $20.3 \mathrm{~b}$ & $26.5 \mathrm{def}$ & $96 \mathrm{~h}$ & $45.9 \mathrm{~m}$ \\
\hline 8 & HATRI 302 & $13 \mathrm{fg}$ & $145 \mathrm{o}$ & $18.9 \mathrm{c}$ & $26.8 \mathrm{~cd}$ & $95 \mathrm{i}$ & 46.81 \\
\hline 9 & HATRI477 & $14 \mathrm{ef}$ & $187 \mathrm{f}$ & $17.5 \mathrm{e}$ & $26.9 \mathrm{c}$ & $99 \mathrm{~g}$ & $44.8 \mathrm{p}$ \\
\hline 10 & HATRI 468 & 15 ef & $176 \mathrm{~h}$ & $16.8 \mathrm{f}$ & $26.4 \mathrm{ef}$ & $153 \mathrm{a}$ & $44.5 \mathrm{r}$ \\
\hline 11 & HATRI 1 & $12 \mathrm{~g}$ & $189 \mathrm{e}$ & $18.9 \mathrm{c}$ & $26.8 \mathrm{~cd}$ & $124 \mathrm{c}$ & $68.9 j$ \\
\hline 12 & HATRI 170 & $10 \mathrm{~h}$ & $163 \mathrm{j}$ & $18.4 \mathrm{~d}$ & $26.8 \mathrm{~cd}$ & $114 \mathrm{e}$ & $95.3 \mathrm{e}$ \\
\hline 13 & HATRI190 & $12 \mathrm{~g}$ & $152 \mathrm{~m}$ & $17.5 \mathrm{e}$ & $26.5 \mathrm{def}$ & $121 \mathrm{~d}$ & $92.4 \mathrm{~g}$ \\
\hline 14 & HATRI192 & $13 \mathrm{fg}$ & $148 \mathrm{n}$ & $16.8 \mathrm{f}$ & 26.7 cde & $112 \mathrm{f}$ & $95.8 \mathrm{~d}$ \\
\hline 15 & HATRI 194 & 14 ef & $199 \mathrm{~d}$ & $20.3 \mathrm{~b}$ & $26.5 \mathrm{def}$ & $49 \mathrm{u}$ & $97.5 \mathrm{c}$ \\
\hline 16 & HATRI60 & $12 \mathrm{~g}$ & $185 \mathrm{~g}$ & $21.3 \mathrm{a}$ & $26.4 \mathrm{ef}$ & $86 \mathrm{k}$ & $99.8 \mathrm{a}$ \\
\hline 17 & HATRI62 & $14 \mathrm{ef}$ & $175 \mathrm{~h}$ & $20.1 \mathrm{~b}$ & $26.5 \mathrm{def}$ & $112 \mathrm{f}$ & $99.5 \mathrm{a}$ \\
\hline 18 & HATRI61 & $15 \mathrm{ef}$ & $126 \mathrm{r}$ & $12.3 \mathrm{kl}$ & $26.3 \mathrm{f}$ & $135 \mathrm{~b}$ & 99.8 a \\
\hline 19 & HATRI144 & 15 ef & $142 \mathrm{p}$ & $10.2 \mathrm{n}$ & $26.8 \mathrm{~cd}$ & $99 \mathrm{~g}$ & $74.2 \mathrm{i}$ \\
\hline 20 & HATRI188 & $9 \mathrm{~h}$ & $158 \mathrm{k}$ & $10.5 \mathrm{n}$ & $26.8 \mathrm{~cd}$ & $86 \mathrm{k}$ & $79.3 \mathrm{i}$ \\
\hline 21 & HATRI195 & $9 \mathrm{~h}$ & $135 \mathrm{q}$ & $15.4 \mathrm{~g}$ & $26.9 \mathrm{c}$ & $68 \mathrm{o}$ & $99.7 \mathrm{a}$ \\
\hline 22 & HATRI 50 & $7 \mathrm{i}$ & $147 \mathrm{n}$ & $14.2 \mathrm{j}$ & 28.7 a & $67 \mathrm{o}$ & $45.2 \mathrm{o}$ \\
\hline 23 & HATRI2 & $4 \mathrm{j}$ & 1561 & $11.2 \mathrm{~m}$ & $24.2 \mathrm{~h}$ & $65 \mathrm{p}$ & $0 \mathrm{y}$ \\
\hline 24 & HATRI3 & $13 \mathrm{fg}$ & $112 \mathrm{v}$ & $10.5 \mathrm{n}$ & $26.8 \mathrm{~cd}$ & $65 \mathrm{p}$ & $77.5 \mathrm{i}$ \\
\hline
\end{tabular}

New lines provided a substantial enhancement in the level of tolerance of all the lines varieties. Only 11 lines (HATRI 1, HATRI 170, HATRI 190, HATRI 192, HATRI 194, HATRI 60, HATRI 62, HATRI 61, HATRI 144, HATRI 188, HATRI 195) carried 90-99\% survival salinity condition in the field.

Use of DNA markers to accelerate progress in breeding for salt tolerance:

Identification of molecular markers associated with quantitative trait loci (QTLs) linked with useful agronomic or adaptive traits will help speed the progress in breeding once developed, because these DNA markers will become effective tools for selection. Moreover, positional cloning using DNA markers will make it possible to isolate agronomically useful genes, which can also be used in breeding across species via transgenic approaches. The study used restriction fragment length polymorphism (RFLP) and 
simple sequence length polymorphism (SSLP) markers to saturate the segment of chromosome 1 containing a major salt tolerance gene controlling the $\mathrm{Na}+\mathrm{K}+$ ratio. RFLP and SSLP analyses were conducted to construct linkage maps based on an F8 recombinant inbred line (RIL) mapping population(Bonilla et al 2002 ) We developed several mapping populations using salt tolerant and sensitive genotypes and used them for mapping of QTLs associated with salinity tolerance during seedling stage(Lang et al., 2001, Lang et al 2015). Two QTLs with relatively large effects were identified, one on chromosome 1 (linked to marker 18EC) and the second on chromosome 8 (linked to marker 12EC). Microsatellite markers closely linked to these loci were identified such as RM223 associated with the QTL on Chromosome 8. This marker was further evaluated for its effectiveness in breeding using a set of 24 improved varieties, including tolerant (Pokkali) and sensitive (IR28) checks. These cultivars were genotyped at this marker and then phenotyped for salinity tolerance at $12 \mathrm{dS} \mathrm{m}^{-1}$ in culture solution (Yoshida et al., 1976) using visual SES scores. The results indicated an accuracy of more than $95 \%$ in identifying tolerant cultivars using this marker (Table 2). These results indicated the usefulness of this marker in parental surveys and in identifying tolerant lines from segregating populations; however, further tests are needed to confirm its effectiveness in different genetic backgrounds. More efforts are needed to develop closely linked markers to these two QTLs to be used for their routine introgression into popular varieties and elite breeding lines.

Table 2. Comparison between the phenotype and genotype of 24 varieties under salt stress of $12 \mathrm{dS} \mathrm{m} \mathrm{m}^{-1}$. Lines were genotyped using markers specific for Saltol locus on chromosome 1 and phenotyped under salt stress in hydroponics

\begin{tabular}{|c|c|c|c|c|}
\hline Number & varieties & Genotype & phenotype & Note \\
\hline 1 & IR28( Checked S) & $S^{¥}$ & $S$ & $\mathrm{~S}$ \\
\hline 2 & PokkaliChecked for R) & $\mathrm{T}$ & $\mathrm{T}$ & $\mathrm{T}$ \\
\hline 3 & HATRI 402 & $S$ & S & S \\
\hline 4 & HATRI503 & $S$ & S & S \\
\hline 5 & HATRI506 & $S$ & S & S \\
\hline 6 & HATRI 507 & $\mathbf{S}$ & $\mathbf{S}$ & $S$ \\
\hline 7 & HATRI 506 & $\mathbf{S}$ & $\mathbf{S}$ & S \\
\hline 8 & HATRI 302 & $S$ & S & $S$ \\
\hline 9 & HATRI477 & $S$ & S & $S$ \\
\hline 10 & HATRI 468 & $S$ & S & S \\
\hline 11 & HATRI 1 & $\mathbf{T}$ & $\mathbf{T}$ & $\mathbf{T}$ \\
\hline 12 & HATRI 170 & $\mathbf{T}$ & $\mathbf{T}$ & $\mathbf{T}$ \\
\hline 13 & HATRI190 & $\mathrm{T}$ & $\mathrm{T}$ & $\mathrm{T}$ \\
\hline 14 & HATRI192 & $\mathrm{T}$ & $\mathrm{T}$ & $\mathrm{T}$ \\
\hline 15 & HATRI 194 & $\mathbf{T}$ & $\mathbf{T}$ & $\mathrm{T}$ \\
\hline 16 & HATRI60 & $\mathbf{T}$ & $\mathbf{T}$ & $\mathrm{T}$ \\
\hline 17 & HATRI62 & $\mathbf{T}$ & $\mathbf{T}$ & $\mathrm{T}$ \\
\hline 18 & HATRI61 & $\mathbf{T}$ & $\mathbf{T}$ & $\mathrm{T}$ \\
\hline 19 & HATRI144 & $\mathrm{T}$ & S & $\mathrm{S}$ \\
\hline 20 & HATRI188 & $\mathbf{T}$ & $\mathbf{T}$ & $\mathrm{T}$ \\
\hline 21 & HATRI195 & $\mathbf{T}$ & $\mathbf{T}$ & $\mathrm{T}$ \\
\hline
\end{tabular}




\begin{tabular}{llllc}
\hline 22 & HATRI 50 & S & S & S \\
23 & HATRI2 & $\mathrm{S}$ & $\mathrm{s}$ & $\mathrm{S}$ \\
24 & Oxy 10(Checked) & $\mathrm{T} / \mathrm{S}$ & $\mathrm{T}$ & Not clear \\
\hline
\end{tabular}

${ }^{¥}$ T: tolerance and S: sensitive. ${ }^{£}$ Oxy 10andPokkali were tested in the field and seeds provided to farmers in several provinces for further testing.

\section{Advancing rice research}

Confronting the huge challenges of developing varieties in the less-favorable rice areas necessitates partnerships and strategies that capitalize on and foster synergism among related projects in Vietnam. Having strong financial support from the government and other external programs, Vietnam has been successful in scientific and development work leading to releases of a significant number of climate-resilient varieties and suitable crop management practices. The well-focused development agenda of the national government has been a driving force in raising the level of productivity in difficult rice ecosystems. Moreover, HATRI institutions has also been instrumental in catalyzing support, resources and capacities that is now creating impact on Vietnam's rice productivity at the farmers' fields, and producing surplus for local and export markets.

The project has been breeding for salinity using MAS, building up on the prior knowledge and system of rice breeding at the (HATRI) institute. In collaboration with other Vietnam institutions, andRice Climate for salinity project, HATRI has developed several climate-resilient rice varieties such as grain quality and salinity-tolerant varieties by intro gressing Saltol and quality QTLs into elite genotypes. For its expansion efforts, partners distributed seeds of salinity tolerant elite lines for field evaluation in farmers' fields. Beginning in 2017, HATRI aim (1) to breed and develop new rice varieties (2-3 varieties) suitable for export standards and adapted to the conditions in the Mekong Delta, salinity tolerant, early- maturing, high-yielding, and with good quality, as well as with resistance to major insects/pests; (2) and to build up technical procedures for cultivation of new rice varieties in salinity tolerance of the Delta.

With HATRI 's involvement in Rice Climate activities, at least fourteen (14) varieties have been supported that have now been doing releases (Table 3). Most of these stress-tolerant varieties can provide, on average, a yield advantage of 1.0- 1.5 tons per hectare compared to the farmers' popular varieties. The average yield of a popular variety in the mid-1990s was only 3.0 tons/ha ( Buu et al 2017). But with the usage of new rice varieties that have been released over the years, the average yield has been increasing and has reached 5.5 tons/ha in 2017 for salinitytolerant varieties, and about 6.0 ton/ha for salinity -tolerant varieties. The released varieties that have been developed through marker-assisted selection (MAS) are TLG 1 (both for salinity- and submergence-prone areas), TLG 1 , and HATRI 170; and for salinity, HATRI60, HATRI 61, HATRI 62. The other varieties in the table have been developed through conventional breeding methods that required at least a decade-worth of work. Results of adaptation trials were used to pass the rigorous evaluation process. For instance, shows the comparative yield performance of three varieties included in trials in 2017-2018, which indicated the good performance of salinity -tolerant varieties, particularly HATRI 10, HATRI 60, TLG1. This eventually became part of the bases for farmers' selection and continued adoption in affected environments to this today.

\section{Yield testing on rice varieties}

To select the rice varieties with high yield potential, insect pest resistance for condition in Mekong delta. To find out the rice varieties with desirable traits for hybridization in rice improvement programs.

Including lines rice varieties with Pokkali, OXY 10 for checked, growing dry seasons 2017-2018. Yield testing experiments were laid out in completely randomized block designs with 3 replications in BaTri's experimental field. Statistical analysis was cited (Gomez and Gomez, 1982). Data records on agronomic characters, yield and yield components were also guided as SES (IRRI, 1996). Insect, disease screening experiments were laid out in single replication. Evaluation of insect and disease reaction at seedling stage (IRRI, 1996). Agronomic characters were presented in table 3 . 
International Journal of Environment, Agriculture and Biotechnology, 5(4)

Jul-Aug, 2020 / Available: https://ijeab.com/

Table 3: Yield and yield components of linesforsalinity in rice at 2017-2018at Ba Triwith salinity EC=10 DS/m

\begin{tabular}{|c|c|c|c|c|}
\hline Lines & Duration (days) & Height $(\mathbf{c m})$ & Panicle $/ \mathbf{m}^{2}$ & Yield (tons/ha) \\
\hline HATRI 1 & 100 & $107 b$ & $303.66 a b$ & 4.473 bcde \\
\hline HATRI 190 & 95 & $109.33 \boldsymbol{b}$ & $266.66 b c$ & $5.13 a b$ \\
\hline HATRI 170 & 96 & $107.33 \boldsymbol{b}$ & $242 c$ & $5.16 a b$ \\
\hline HATRI 194 & 100 & $108 \boldsymbol{b}$ & $274 \boldsymbol{b c}$ & 4.726 abcde \\
\hline HATRI62 & 105 & $108.33 \boldsymbol{b}$ & $284 a b c$ & 4.95 abcd \\
\hline HATRI 188 & 98 & $95.66 d$ & $284.33 a b c$ & $3.84 \mathrm{cde}$ \\
\hline HATRI144 & 98 & $115 a$ & $272.66 b c$ & 4.69 abcde \\
\hline HATRI192 & 95 & $106.66 \boldsymbol{b}$ & $290.33 a b c$ & $5.84 a$ \\
\hline TLG1 & 94 & $98.67 c d$ & $293.67 a b c$ & 4.35 bcde \\
\hline HATRI 195 & 100 & $101.67 c$ & $338.33 a$ & 4.32 bcde \\
\hline POKKALI & 115 & $129.67 \mathrm{e}$ & $318.67 \boldsymbol{a b}$ & $3.66 e$ \\
\hline OXY 10 (Checked) & 105 & $101.33 c$ & $285.33 a b c$ & $3.8 \mathrm{de}$ \\
\hline HATRI475 & 95 & $99.33 \mathrm{~cd}$ & $287.67 a b c$ & 4.07 bcde \\
\hline HATRI60 & 95 & $107.33 \boldsymbol{b}$ & $320 a b$ & $5.09 a b c$ \\
\hline$C V$ & 0 & 2.16 & 10.16 & 14.26 \\
\hline
\end{tabular}

It is indicated that almost of rice varieties in experiment are less than 100 days duration. Plant height ranged in $120 \mathrm{~cm}$ for Pokkali.

Grain yield and yield components of 16lines rice and were presented in table 4.It was indicated that HATRI 90 and HATRI 192 gave highest yield in experiment (5.13 - 5.16 tons/ha) and be higher thanOxy 10 (checked Rice famers )

The success of new varieties is assured through eventual testing and selection in target sites in partnership with farmers and under their own management to guarantee relevance and adoption. Special emphasis is placed on crop establishment because the early stages of seedling growth are extremely sensitive to salt stress (Moradi et al., 2003; Ismail et al., 2007. Lang et al 2018). This is achieved through combined use of salt tolerant genotypes, coupled with proper nursery management and seedling handling that ensures maximum survival of transplanted seedlings.

Combination of traits for multiple stresses. One of the difficulties in rice areas severely affected by variability in climatic conditions is the occurrence of multiple stresses over a cropping season. To address this concern and with the advances in molecular biology particularly using MAS, the breeding program of HATRI used pyramiding technique to combine genes responsible for tolerance to a combination of stresses. For instance, in 2017, in developing high-yielding rice varieties tolerant to salinity and quality total of ten (10) single and multiple crosses were done for combining sality and quality rice into the high-yielding genetic background. Genetic diversity is emphasized as a success factor in breeding, as well as in understanding the relationship between genotype and phenotype. Strategic development of the varieties focus on the following: (a) adaptation to effects of sality, both at the seedling stage and flowering stage, (b) improved yield to exceed 5-6 tons/ha, and (c) providing the basis of genetic diversity.

Emphasis on grain quality. Grain quality is considered an important trait contributing to farmers' preference or selection of a variety. This is also taken into consideration in breeding works to know which traits are most popular among traders. For instance, to develop long and medium grain rice cultivars, 20 crosses were made in 2017. The F2, BC1, BC2, $\mathrm{BC} 3$ seeds were planted at HATRI in the wet season and dry season. Samples of seed from each harvested plant were sent to the Riceland quality lab for grain quality evaluation at HATRI and selected crosses were evaluated using MAS for amylose content, aroma and blast resistance. The best yielding lines selected from these experiments were advanced to the HATRI. Twenty advanced long grain lines were also tested in the 6 provinces for trials, indicating that long grain rice cultivars could be ready for release in the near future. 
International Journal of Environment, Agriculture and Biotechnology, 5(4)

Jul-Aug, 2020 / Available: https://ijeab.com/

Table 4. Most in-demand stress-tolerant varieties and their characteristics

\begin{tabular}{|c|c|c|c|c|c|c|c|c|c|c|}
\hline Genotype & $\begin{array}{l}\text { Maturity } \\
\text { (days) }\end{array}$ & Origin & $\begin{array}{c}1000 \\
\text { grain } \\
\text { wt. (g) }\end{array}$ & $\begin{array}{l}\text { Amylos } \\
\text { e } \\
(\%)\end{array}$ & $\begin{array}{c}\text { Cooked rice } \\
\text { quality }\end{array}$ & BPH & Blast & $\begin{array}{c}\text { BLB } \\
\text { (score) }\end{array}$ & $\begin{array}{c}\text { Yield } \\
\text { (ton/ha) }\end{array}$ & Remarks by farmers \\
\hline \multicolumn{11}{|c|}{ Salinity-tolerant and good quality varieties } \\
\hline OM4900 & $95-100$ & $\begin{array}{l}\text { Origin: } \\
\text { C53/ } \\
\text { Jasmine } \\
85 /\end{array}$ & 28.8 & 16.8 & $\begin{array}{l}\text { Glutinous, and aromatic rice, } \\
\text { "World's longest cooking rice"; } \\
\text { excellent for cooking, requires } \\
\text { less water }\end{array}$ & Tolerant & Tolerant & $3-5$ & $7-8$ & $\begin{array}{c}\text { Excellent (Salinity- } \\
\text { tolerant, high yield, aroma) } \\
\text { no lodging }\end{array}$ \\
\hline HATRI 10 & $95-100$ & & 27.5 & 19.6 & $\begin{array}{l}\text { Glutinous, soft, excellent for } \\
\text { cooking, elongation trait, } \\
\text { requires less water }\end{array}$ & Tolerant & Tolerant & 5 & $6-8.5$ & $\begin{array}{l}\text { Good (Salinity-tolerant) } \\
\text { KienGiang, Bac Lieu, and } \\
\text { TraVinh (5\% of areas } \\
\text { grow this variety) }\end{array}$ \\
\hline TPG1 & $93-85$ & $\begin{array}{c}\text { hybrid of } \\
\text { M362/A } \\
\text { S996 }\end{array}$ & 25.6 & 22 & Glutinous & Tolerant & Tolerant & $3-5$ & $6-8$ & $\begin{array}{l}\text { Very good (Salinity- } \\
\text { tolerant, high yielding) }\end{array}$ \\
\hline $\begin{array}{l}\text { HATRI } \\
170\end{array}$ & $95-100$ & & 26 & 22 & Glutinous, hard & Tolerant & Tolerant & $3-5$ & $5-7$ & $\begin{array}{l}\text { Very good (Salinity- } \\
\text { tolerant, high yielding) }\end{array}$ \\
\hline TLG1 & $95-100$ & $\begin{array}{l}\text { Origin: } \\
\text { OMCS2 } \\
012 / \\
\text { Pokkali }\end{array}$ & 27.3 & 21.5 & Glutinous & Tolerant & Tolerant & $3-5$ & $5-7$ & $\begin{array}{c}\text { Excellent (Salinity- } \\
\text { tolerant, high yielding); } \\
\text { Bac Lieu, KienGiang and } \\
\text { TraVinh; farmers liked the } \\
\text { variety that }>408 \text { ha in } \\
2009 \text { and increased to } \\
1,496 \text { ha in the Mekong } \\
\text { Delta in } 2010 .\end{array}$ \\
\hline HATRI144 & $90-95$ & & 27.5 & 21.86 & Glutinous & Tolerant & Tolerant & 3 & $5-7$ & $\begin{array}{l}\text { Good (high yielding), } \\
\text { tolerant to salinity, } \\
\text { alkalinity, iron and boron } \\
\text { toxicity, and phosphorous } \\
\text { and zinc deficiency; }\end{array}$ \\
\hline
\end{tabular}


International Journal of Environment, Agriculture and Biotechnology, 5(4)

Jul-Aug, 2020 / Available: https://ijeab.com/

\begin{tabular}{|c|c|c|c|c|c|c|c|c|c|}
\hline & & & & & & & & & $\begin{array}{l}\text { suitable in irrigated and } \\
\text { rainfed lowland areas; } \\
\text { popularly grown in } \\
\text { salinity- and alkaline rice } \\
\text { areas such as KienGiang, } \\
\text { TraVinh and Long An }\end{array}$ \\
\hline HATRI 61 & $95-105$ & 27.5 & 23.5 & Glutinous & Tolerant & Tolerant & $3-5$ & $5-7$ & $\begin{array}{l}\text { Good (Salinity-tolerant, } \\
\text { high yielding) tolerant to } \\
\text { salinity, alkalinity, iron } \\
\text { and boron toxicity, and } \\
\text { phosphorous and zinc } \\
\text { deficiency; suitable in } \\
\text { irrigated and rainfed } \\
\text { lowland areas }\end{array}$ \\
\hline HATRI 20 & $95-105$ & 26.8 & 23 & Glutinous & Tolerant & Tolerant & 5 & $5-7.5$ & $\begin{array}{l}\text { Very good (Salinity- } \\
\text { tolerant, high yielding) }\end{array}$ \\
\hline HATRI192 & $95-100$ & 25.6 & 21 & Glutinous and scent & Tolerant & Tolerant & $3--5$ & $6-7$ & $\begin{array}{l}\text { Good (drought, high } \\
\text { yielding) }\end{array}$ \\
\hline $\begin{array}{l}\text { HATRI } \\
144\end{array}$ & $105-110$ & 26.5 & 24.5 & Glutinous & No data & No data & $3--5$ & $3-4$ & $\begin{array}{l}\text { Excellent (drought- } \\
\text { tolerant) }\end{array}$ \\
\hline $\begin{array}{l}\text { HATRI } \\
181\end{array}$ & $95-100$ & 28.8 & 16.8 & Glutinous and scent & Tolerant & Tolerant & $3-5$ & $7-8$ & $\begin{array}{l}\text { Very good (drought - } \\
\text { tolerant, high yielding, } \\
\text { aromatic) }\end{array}$ \\
\hline HATR60 & $95-100$ & 27.5 & 22 & Glutinous & Tolerant & Tolerant & 5 & $7-8.5$ & $\begin{array}{l}\text { Very good (sality-tolerant, } \\
\text { droughthigh yielding) }\end{array}$ \\
\hline
\end{tabular}

\section{Evaluation of salinity stress varieties in farmers' fields}

Performance stability is one of the most important properties of a genotype to be released as a variety to ensure wide adoption. To ensure this, we tested 12 indica rice verities at 7 different locations during the wet season 2018 and dry seasons of 2018-2019, using a randomized block design with three replications in each case. Duration, grain yield ( $\mathrm{t} \mathrm{ha}^{-1}$ were presented in Table 4, 5. The experiment was conducted in 7 provinces, Can tho (checked),TraVinh, Ca Mau, SocTrang,Long An, Ben Tre and Bac 
International Journal of Environment, Agriculture and Biotechnology, 5(4)

Jul-Aug, 2020 / Available: https://ijeab.com/

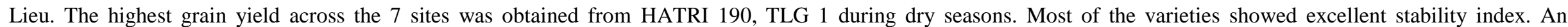

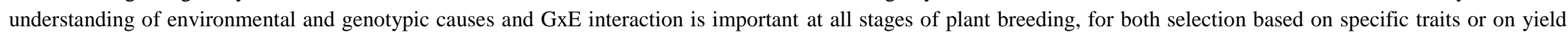
(Yan and Hunt, 1998; IRRI, 1997)

Table 5.The Yield of 12 lines in riceat Mekong delta dry season 2018-2019

\begin{tabular}{|c|c|c|c|c|c|c|c|c|c|}
\hline \multirow{3}{*}{ Numbers } & \multirow{3}{*}{ Lines } & \multicolumn{6}{|c|}{ Mekong delta } & \multirow{3}{*}{ Can Tho } & \multirow{3}{*}{ mean } \\
\hline & & \multirow{2}{*}{ Bac Lieu } & \multirow{2}{*}{$\begin{array}{c}\text { Ba Tri } \\
\text { (Ben Tre }\end{array}$} & \multirow{2}{*}{ Ca Mau } & \multirow[b]{2}{*}{ Long An } & \multirow[b]{2}{*}{ TraVinh } & \multirow[b]{2}{*}{ SocTrang } & & \\
\hline & & & & & & & & & \\
\hline 1 & HATRI 1 & 7.55 & 7.81 & 7.68 & 7.00 & 6.17 & 7.52 & 7.90 & 7.37ab \\
\hline 2 & HATRI 190 & 7.80 & 7.77 & 7.79 & 6.9 & 7.87 & 7.78 & 8.10 & $7.71 \mathrm{a}$ \\
\hline 3 & HATRI 170 & 7.28 & 7.28 & 7.29 & 7.51 & 7.75 & 7.56 & 7.80 & 7.49ab \\
\hline 4 & HATRI 475 & 7.52 & 7.84 & 7.53 & 7.05 & 6.84 & 7.67 & 7.10 & 7.36ab \\
\hline 5 & HATRI62 & 7.39 & 7.01 & 7.21 & 7.16 & 7.53 & 7.78 & 6.50 & 7.22ab \\
\hline 6 & HATRI 60 & 7.44 & 7.24 & 6.71 & 7.63 & 7.97 & 6.25 & 7.65 & 7.27ab \\
\hline 7 & HATRI 188 & 7.55 & 7.43 & 7.89 & 7.20 & 7.58 & 7.93 & 6.42 & 7.42ab \\
\hline 8 & HATRI144 & 7.07 & 7.16 & 7.26 & 7.52 & 7.31 & 7.57 & 7.12 & 7.28ab \\
\hline 9 & HATRI192 & 7.12 & 7.45 & 7.61 & 7.27 & 6.62 & 7.58 & 7.47 & 7.30ab \\
\hline 10 & TLG1 & 7.64 & 7.85 & 7.12 & 7.59 & 7.32 & 7.73 & 7.93 & 7.59ab \\
\hline 11 & HATRI194 & 7.37 & 7.48 & 6.47 & 7.48 & 7.72 & 7.04 & 7.30 & 7.26ab \\
\hline 12 & Oxy 10 (check) & 6.52 & 7.29 & 6.9 & 7.23 & 7.08 & 6.84 & 6.97 & $6.97 b$ \\
\hline & EMS & 0.272 & 0.17 & 0.16 & 0.13 & 0.12 & 0.16 & 0.14 & \\
\hline & Mean & 6.43 & 6.63 & 6.12 & 5.79 & 5.81 & 5.68 & 6.93 & \\
\hline & $\left(\mathbf{I}_{\mathbf{j}}\right)$ & 0.24 & 0.44 & -0.07 & -0.39 & -0.38 & -0.50 & 0.74 & \\
\hline
\end{tabular}


International Journal of Environment, Agriculture and Biotechnology, 5(4) Jul-Aug, 2020 / Available: https://ijeab.com/

Table 6.The yield of 12 lines in rice at Mekong delta on 20018 wet season

\begin{tabular}{|c|c|c|c|c|c|c|c|c|}
\hline \multirow[b]{2}{*}{ Lines } & \multicolumn{6}{|c|}{ Mekong } & \multirow{2}{*}{\multicolumn{2}{|c|}{ Can Tho }} \\
\hline & BacLieu & Ba Tri & Ca Mau & Long An & TraVinh & SocTrang & & \\
\hline HATRI 1 & $5.62 \mathrm{ab}$ & 5.54ab & 5.86ab & 5.70ab & $6.00 a$ & 5.40ab & $5.69 \mathrm{ab}$ & \\
\hline $\begin{array}{l}\text { HATRI } \\
190\end{array}$ & $5.80 \mathrm{ab}$ & $5.70 \mathrm{ab}$ & $5.40 \mathrm{ab}$ & $5.30 \mathrm{ab}$ & $5.00 \mathrm{ab}$ & $4.50 \mathrm{~b} a b$ & $5.28 \mathrm{ab}$ & \\
\hline $\begin{array}{l}\text { HATRI } \\
170\end{array}$ & $5.88 \mathrm{ab}$ & $5.33 \mathrm{ab}$ & $5.70 \mathrm{ab}$ & $4.90 \mathrm{~b}$ & $5.20 \mathrm{ab}$ & $4.85 \mathrm{~b}$ & $5.06 \mathrm{ab}$ & \\
\hline $\begin{array}{l}\text { HATRI } \\
475\end{array}$ & $5.70 \mathrm{ab}$ & $5.10 \mathrm{ab}$ & $5.20 \mathrm{ab}$ & $5.00 \mathrm{ab}$ & $5.40 \mathrm{ab}$ & $5.20 \mathrm{ab}$ & $4.86 \mathrm{ab}$ & \\
\hline HATRI62 & $5.40 \mathrm{ab}$ & $4.90 \mathrm{~b}$ & $5.00 \mathrm{~b}$ & $4.80 \mathrm{~b} a b$ & $5.10 \mathrm{ab}$ & $5.15 \mathrm{ab}$ & $5.76 \mathrm{ab}$ & \\
\hline HATRI 60 & $5.46 \mathrm{ab}$ & $5.15 \mathrm{ab}$ & $5.30 \mathrm{ab}$ & $5.80 \mathrm{ab}$ & $5.15 \mathrm{ab}$ & $5.00 \mathrm{ab}$ & 4.93ab & \\
\hline $\begin{array}{l}\text { HATRI } \\
188\end{array}$ & $5.46 \mathrm{ab}$ & $5.90 \mathrm{ab}$ & $6.20 \mathrm{a}$ & $5.75 \mathrm{ab}$ & $5.80 \mathrm{ab}$ & $6.00 \mathrm{a}$ & $5.85 \mathrm{a}$ & \\
\hline HATRI144 & $6.20 \mathrm{a}$ & $6.00 \mathrm{a}$ & $5.90 \mathrm{ab}$ & $5.30 \mathrm{ab}$ & $6.10 \mathrm{a}$ & $6.00 \mathrm{a}$ & $6.33 a$ & \\
\hline HATRI192 & $4.84 \mathrm{~b}$ & $5.80 \mathrm{ab}$ & $5.55 \mathrm{ab}$ & $5.20 \mathrm{ab}$ & $5.35 \mathrm{ab}$ & $5.50 \mathrm{ab}$ & $5.93 \mathrm{ab}$ & \\
\hline TLG1 & $5.62 \mathrm{ab}$ & $5.85 \mathrm{ab}$ & $5.70 \mathrm{ab}$ & $5.40 \mathrm{ab}$ & $5.10 \mathrm{ab}$ & $5.20 \mathrm{ab}$ & $5.48 \mathrm{ab}$ & \\
\hline HATRI194 & $5.50 \mathrm{ab}$ & $5.70 \mathrm{ab}$ & $5.60 \mathrm{ab}$ & $5.10 \mathrm{ab}$ & $5.30 \mathrm{ab}$ & $5.00 \mathrm{ab}$ & $5.37 \mathrm{ab}$ & \\
\hline $\begin{array}{l}\text { Oxy } 10 \\
\text { (check) }\end{array}$ & $4.67 \mathrm{~b}$ & $4.85 b$ & $4.55 b$ & $4.80 \mathrm{~b}$ & $4.85 \mathrm{~b}$ & $4.77 \mathrm{~b}$ & $4.75 b$ & \\
\hline & & 14.59 & 15.37 & 14.67 & 17.05 & 15.41 & 14.57 & 11.24 \\
\hline & & 0.88 & 0.75 & 0.71 & 0.79 & 0.73 & 0.67 & 0.53 \\
\hline
\end{tabular}




\section{Potential application site}

For the salinity-tolerant varieties, scaling up can be done by region, where the stresses have been determined and estimated. In different provinces, based on results of multi-location trials, the following are the potential expansion areas for dissemination and farmers' use of the now popular varieties (Table 7).

Table 7. Potential areas for expansion of salinity-tolerant varieties.

\begin{tabular}{|c|c|c|c|c|}
\hline Province (District) & $\begin{array}{l}\text { Yield Potential } \\
\text { (tons/ha/cropping) }\end{array}$ & $\begin{array}{l}\text { Cropping } \\
\text { intensity (/year) }\end{array}$ & $\begin{array}{l}\text { Level of Salinity } \\
\text { (indicate level of } \\
\text { EC) }\end{array}$ & Recommended varieties \\
\hline Bạc Lieu (HoaBinhTown) & $5-6$ tons/ ha & 3 & $\mathrm{EC}=8-10 \mathrm{ds} / \mathrm{m}$ & $\begin{array}{l}\text { Region of } 3 \text { crops: } 2 \text { for salinity } \\
\text { and another crop } \\
\text { HATRI170, HATRI } 144\end{array}$ \\
\hline $\begin{array}{l}\text { Tra Vinh } \\
\text { (Cau Ke district) }\end{array}$ & $\begin{array}{l}\text { 6-7 tons under } \\
\text { normal condition; } \\
\text { under saline soil, } \\
\text { yield is lower at } \\
4-5 \text { tons/ha }\end{array}$ & 2 & $\mathrm{EC}=8-10 \mathrm{ds} / \mathrm{m}$ & $\begin{array}{l}\text { HATRI 20, HATRI 190, HATRI } \\
192\end{array}$ \\
\hline SocTrang & $6-6.2$ tons & $\begin{array}{l}2 \text { varieties + } \\
\text { another crop }\end{array}$ & $\begin{array}{l}\mathrm{EC}=10-12 \\
\mathrm{ds} / \mathrm{m}\end{array}$ & HATRI170 \\
\hline Ben Tre & $5-6$ ton/ ha & $\begin{array}{l}2 \text { cropping, since } \\
\text { areas are severely } \\
\text { affected by } \\
\text { salinity }\end{array}$ & $\begin{array}{l}\mathrm{EC}=12-15 \\
\mathrm{ds} / \mathrm{m}\end{array}$ & $\begin{array}{l}\text { HATRI170, HATRI 190, HATRI } \\
\text { 192, HATRI } 475\end{array}$ \\
\hline $\begin{array}{l}\text { Ca Mau } \\
\text { (Tran van Thoi District) }\end{array}$ & $\begin{array}{l}3-5 \text { tons/ha } \\
\text { (yield is very low } \\
\text { caused by salt, } \\
\text { sulfate soil, and } \\
\text { drought) }\end{array}$ & 1 crop & $\begin{array}{l}\mathrm{EC}=12-15 \\
\mathrm{ds} / \mathrm{m}\end{array}$ & HATRI 170, HATRI 144 \\
\hline Kiengiang & 6-7 tons/ha & 2 crops & $\begin{array}{l}\mathrm{EC}=12-15 \\
\mathrm{ds} / \mathrm{m}\end{array}$ & HATRI60, HATRI 62 \\
\hline
\end{tabular}

\section{DISCUSSION}

Salt- affected soils of the Mekong delta are highly degraded, with a complex of abiotic stresses including salinity, acid sulfate, toxic levels of aluminum and iron and deficiency in some nutrients such as $\mathrm{P}$ and $\mathrm{K}$. To enhance and sustain productivity of these soils, we adopt an integrated approach involving the development of adapted high yielding and salt tolerant varieties developed via novel breeding methods, proper management of resources and introduction of effective cropping patterns that cam meet farmers' needs and market demands( CGIAR .2016).
In different provinces, based on results of multi-location trials, the following are the potential expansion areas for dissemination and farmers' use of the now popular varieties (Table 7).The strong advocates of technology are still the leaders of the locality, who are normally the president of the commune and director of province of the agriculture agency.Farmers observe the trials or their neighbors' field and exchange of information among themselves. If the local community does not accept or refuses to accept the technology or rice variety, the varieties cannot be applied and disseminated.While it depends on the province, the farmers typically make the decision to adopt or refuse to 
grow the new rice varieties. And because it is difficult to convince farmers to grow a particular variety, sometimes unexpected difficulties in the management delay or hamper the dissemination such that the new rice varieties do not reach all farmers. Messengers from farmers also significantly decide on the adoption of newly released rice varieties.

\section{CONCLUSIONS AND FUTURE PROSPECTS}

Development of salt tolerance varieties is generally considered the most effective entry point for improving productivity of salt affected soils, and it is also the cheapest option for farmers. Through the use of innovative breeding strategies involving conventional and modern tools, together with effective phenotyping techniques, good progress was made in developing salt tolerant varieties with broad adaptation to the conditions of the Mekong Delta. Some varieties such as HATRI 190, HATRI 170, HATRI 192were developed that can yield4-5 tons ha ${ }^{-1}$ under 8.0 to $10.0 \mathrm{dS} \mathrm{m}^{-}$ ${ }^{1}$, and are being out-scaled. The success of new varieties is assured through eventual testing and selection in target sites in partnership with farmers and under their own management to guarantee relevance and adoption. This is achieved through combined use of salt tolerant genotypes, coupled with proper nursery management and seedling handling that ensures maximum survival of transplanted seedlings. .

Future efforts should focus on further collection and evaluation of local germplasm to identify landraces with greater tolerance of salt stress, as sources of new genes or alleles for breeding. Additional breeding efforts such as mutation breeding and identification of soma clonal variants should continue to develop better pre-breeding material. To benefit from the new and exciting developments in the field of genomics, additional resources and efforts should be directed towards identification of QTLs and genes underlying tolerance to the multiple stresses experienced in these problem soils of Mekong Delta, for their subsequent integration into modern varieties and elite breeding lines through marker aided breeding. Special efforts should also be placed on training of young scientists to prepare a new generation that can effectively tackle these problems in a team approach.

In the future, stronger linkages and exchange of knowledge through project networks and meetings will also give considerable impacts on capacity strengthening, as well as meeting with scientists, extension workers, civil society organizations in affected areas to plan on the distribution of seed and other adaptation activities to assure farmer acceptance of seed, and determine the quantity of seed required for distribution. Consultation and meetings with people from different sectors involved in the project will also address the development of seed multiplication plan for different varieties needed for different areas identifying the most likely partners to participate in the finalization of seed development and distribution; and identifying training needs of these in terms of technology adaptation, evaluation, and dissemination.

\section{ACKNOWLEDGEMENTS}

The authors are grateful to Ministry of Science and Technology, VietNam (Tay Nam Bo program) and Cuulong Uviversity for funding this research on rice. Appreciation is expressed for the HATRI provided for the project, and to our colleagues in Genetics and Plant Breeding Division (HATRI) for their support and valuable suggestions.

\section{REFERENCES}

[1] Bui Chi Buuand Nguyen thi Lang2004: Improve variety at Mekongdelta to 2010. Science \&technology.Volume8: 10411043).

[2] Bonilla P.S ;Jan Dvorak;David James Mackill, K. deal ;Glenn B. Gregorio.2002.RFLP and SSLP mapping of salinity tolerance genes in chromosome 1 of rice (Oryza sativa L.) using recombinant inbred lines.hilippine Agricultural Scientist 65(1):68-76

[3] Chi Buu Bui, Thi Lang Nguyen. 2017. New rice varieties adapted to climate change in the Mekong River Delta of Vietnam. Life Science/ Agriculture. Vietnam Journal of Science and Technology; vol.59; No.2: 30-33 .

[4] CGIAR. Assessment Report: The drought and salinity intrusion in the Mekong River Delta of Vietnam. Hanoi, Vietnam: CGIAR Research Program on Climate Change, Agriculture and Food Security, 2016

[5] De La Normita CRUZ, Ish KUMAR, Rajendra P. KAUSHIK, Gurdev S. KHUSH.1989 Effect of Temperature During Grain Development on Stabilrty of Cooking Quality Components in Rice. Japanese Journal of breeding, Volume 39 Issue 3 Pages 299-306

[6] Hasegawa, P.M., R.A.J. Versan, K. Zhu and H.J. Bonhert. 2000. Plant cellular and molecularresponses to high salinity. Ann. Rev. Plant Physiol. and Plant Mol. Biol., 51: 463-499.

[7] Kersten Clauss; Marco Ottinger; Patrick Leinenkugel;Claudia Kuenzer.2018. Estimating rice production in the Mekong Delta, Vietnam, utilizing time series of Sentinel-1 SAR data.International Journal of Applied Earth Observation and Geoinformation 2018(73):574-585 
[8] Ismail A.M., Heuer S., Thomson M.J., Wissuwa M. 2007. Genetic and genomic approaches to develop rice germplasm for problem soils. Plant MolBiol (DOI: 10.1007/s11103-0079215-2)

[9] IRRI, 1999. Experimental Design and data analysis for agricultural research. Volume 2.277 paper

[10] IRRI, 2007.Standard evalution system for submergence in rice, international rice research insitute, Los Banos, Philippines.

[11] Lang NT. 2002. Protocol for basic of biotechnology. Agricultural Publisher, Ho chi Minh City, Vietnam

[12] Lang NT, S Yanagihara, BC Buu. 2001. A microsatellite marker for a gene conferring salt tolerance on rice at the vegetative and reproductive stages. SABRAO 33 (1):1-10

[13] Lang,NT. 1999. QTL mapping for salt tolerance in rice.final report. Japan fellowship.

[14] Nguyen thi Lang, Nguyen trongPhuoc, Pham thithu Ha, Tran BaoToan,Bui Chi Buu, Russell Reinke, Abdelbagi M, Ismail. Reiner. Wassmann. 2015. Selection of promising lines with combination of drought and submergence tolerance traits in F7 generation through molecular marker in rice. Omon rice No.20. P:1-8

[15] Nguyen Thi Lang, Pham Cong Tru, Nguyen Van Hieu, Nguyen TrongPhuoc, Tran BaoToan, Tran Minh Tai, Bui Chi Buu. 2016a. Rice seed production suspected of climate change in the Mekong Delta. International Workshop on Crop Science. the second time. No. 8. Pages: $859-875$

[16] Nguyen thiLang, Nguyen TrongPhuoc.2018. Development of new varieties Such as: BL 12. Paper 34

[17] Yan, W., and L.A. Hunt, 1998. Genotype by environment interaction and crop yield. Plant breed. Rev. 16:135-178

[18] Yoshida, S., Forno, D.A., Cock, J.H., Gomez, K.A., 1976. Laboratory manual forphysiological studies of rice $3^{\text {rd }}$ ed. Manila (Philippines); Int. Rice Res. Institute.

[19] Zheng K., N. Huang, J. Bennett, GS. Khush. 1995. PCR-based marker assisted selection in rice breeding. IRRI discussion paper series No. 12. International Rice Research Institute, P. O. Box 933, Manila, Philippines. 